\title{
Social Welfare Impacts of Imposing an Import Tariff on Maize Market in Iran Compared to an Export Tax in China and Brazil Using: a Game Theory Approach
}

\author{
Amir Hossein Chizari (Corresponding author) \\ Faculty of Agricultural Economics Department, College of Agriculture \& Natural Resources \\ University of Tehran, Iran \\ Tel: 98-263-224-7783Ｅ-mail: chizari8000@ut.ac.ir \\ Fereshte Assadollahpour \\ PHD student of Tabriz University \\ E-mail: fereshteassa@yahoo.com \\ Safdar Hosseini \\ Faculty of Agricultural Economics Department, College of Agriculture \& Natural Resources \\ University of Tehran, Iran \\ E-mail: hoseini@ut.ac.ir
}

Received: March 13, 2013 Accepted: April 2, 2013 Published:

doi:10.5296/jas.v1i2.3853 URL: http://dx.doi.org/10.5296/jas.v1i2.3853

\begin{abstract}
The social welfare impacts of Iran's maize import policies versus China and Brazil export policies using a game theoretic approach. The economy of maize export by China and Brazil as well as Iran's import demand are analyzed using empirical imports models. In this study, supply, demand, imports and price equations are estimated using a three-stage least squares (3SLS) model to obtain elasticities. The estimated elasticities are incorporated in a non-cooperative dynamic game framework to analyze the possible impacts of policy changes in these three countries. This study analyzes various policies, including several scenarios regarding changes in Iran's import tariff from $0 \%$ to $10 \%$ with respect to China and Brazil
\end{abstract}


exported price ratio (export tax on domestic price of Iran) from 0.56-1.36. The results indicate that Iranian government should impose a tariff rate approximately $8 \%$ to maximize its own social welfare considering export taxes of 0.98 and 0.93 imposed by China and Brazil respectively. The results also suggest that policy makers in Iran should focus more on Iran's tariff rates rather than export taxes imposed by China and Brazil.

Keywords: Game Theory, Social welfare, Tariff Rate, Export Tax, Maize Import

\section{Introduction}

Maize is the third largest planted crop after wheat and rice in the world (Salvador,1997). Maize is one of the strategic products in Iran. It is used as a leading feed and thought to be the most important source for providing energy (i.e. 65-70\%) in the poultry industry.. In 2009, approximately 2 million tons of maize equivalent to 75 percent of domestic consumption was imported from China and Brazil which they are the main sources for Iran's maize imports. Brazil is emerged as an important supplier of maize to the world market in recent years. And China has become a major competitor to the United States in the Asian market and around the world. China and Brazil are the world's largest maize exporters and their maize policies can be expected to affect world maize prices thereby influencing the social welfare of other exporters and importers. Iran is a small country in terms of the volume of maize trade and its policies do not affect world prices. However, Iran's policy makers can adjust the tariff rate on imports when the world price changes and thus influence domestic social welfare.

The impact of food price levels on the welfare of producers and consumers in Iran has led that governments to seek right import policies on maize import. The Iranian government intervenes in the maize market with major political and economic support to protect producers and consumers and to prevent its price rise. Various policies can be used to influence the balance between production and consumption, including tariffs, the volume of maize markets, input subsidies, credit programs, guaranteed prices (Najafi,1999; Bakhshoode and Thomson, 2006). The import tariff is one of the main policy for market regulation in Iran. Since the production cost of maize in Iran is higher compared to other countries such as China and Brazil, the Iranian governments impose a import tariff to support domestic producers. The minimum, maximum and average tariff rates applied to Iranian maize imports have been $0 \%, 5 \%$ and $3 \%$, respectively over the period of 1989-2009. The average tariff rate in 2009 has been $4 \%$. In this research, to assess the impact of a tariff rate on social welfare, tariff rates ranging from $0 \%$ to $10 \%$ is considered.

Brazil and China have a long history of taxing their maize exports. The principal policy variable in these countries is the export tax, which is used to regulate the amount of export to support domestic consumers. Iran is among the world's major importer of maize, with an approximately 3.3 million tons import over the period of 2008-2009. This is about $4 \%$ of world maize imports with C.V $=0.28$. According to Brazil's export statistics, corn exports to Iran are estimated to be 1.9 million tons, indicating a 27 percent increase in 2009 compared to 2008. Maize imports from China in 2009 was 1.2 million tons while the figure was 1.8 million tons in 2007. Brazil and China are the large maize exporter countries to Iran, so reducing in their exports international supply cause an increase in the export price relative to 
world price of maize and in Iran. Taxation generates revenue for governments and changes exporter surplus. We consider changes in the rate of tax (from the base amount) that result in an increase and decrease in the ratio of export prices to domestic prices ranging from 0.56 to 1.36. This research investigates how the maize export policy of Brazil, China and import policies of Iran are interacted and how its world price changes impact on Iran's social welfare.

\subsection{Literature Review}

There have been several studies focused on relating the impact of policy reform and trade liberalization of agricultural commodities and Iran's corn import. Dae-Seob Lee (2002) estimate econometric models of supply and consumption behavior, to determine the political weights of relevant interest groups, to conduct a game theoretic analysis to determine the optimal policy options for U.S. rice exports to Japan and Korea found that the best export policy option from the U.S. perspective is obtained at a $4 \%$ tariff reduction for Japan and Korea under a combination of U.S. market access program and foreign market development program. Yazdani (2008) determinate corn import demand for Iran, fundamentally for policy-making purposes whit estimating single equation model, the results show that indicates such as: per capita national disposal income, domestic product, domestic consumption, governmental stock corn, can be relative by corn prices. Burhan Ozkan (2001) concerned Game theory with competitive situations. Farm planning problems conceive the farmer playing a game against nature. A two-person zero-sum game can be converted into a linear programming model due to several similarities between the two. Therefore, the optimal solution to game theory may be found by formulating it as a linear programming problem. The objective of the game theory model in agriculture is to find the highest income under the worst circumstances. Salami (2011) whit considering the relationship between wheat and barley, calculated the Policy preference function for each market separately And whit applying appropriate policy weighting, game theory has been applied to assess the welfare effects of this policy. Bakhshode (2012) analyzed the relationship between rice imports of Iran from Thailand whit game theory. The results show that Nash equilibrium obtained whit imposing a tariff rate approximately $3 \%$ for Iran and a $3 \%$ increase in export prices in Thailand.

\subsection{Hypothesis}

The general hypothesis of this study is to investigate the effect of import tariff policy of Iran and export price of China and Brazil on social welfare of Iranian consumer and producer.

\section{Methodology}

Econometric estimates of relevant iran supply, demand, price and import (from China and Brazil) functions are incorporated into a game theory analysis to obtain Nash equilibrium.

The import equation is:

$$
\log M I_{t}^{d}=a_{0}+a_{1} \log \left(\frac{p m_{i}}{p d_{i}}\right)+a_{2} \log G D P+a_{3} \log E R_{t}+a_{4} \log D M_{t}+a_{5} L Q_{t}+\log U_{t 1}
$$


where $\mathrm{MI}_{\mathrm{t}}^{\mathrm{d}}$ is import of maize, $\left(\frac{p m_{i}}{p d_{i}}\right)$ is the lagged Ratio of export prices to domestic prices of maize and GDP is gross domestic production of Iran, $Q_{t}$ is domestic production of maize in Iran, ER and DM are The real exchange rate and tariff rate respectively. The signs of $a_{1}, a_{3}, a_{4}$ and $a_{5}$ are expected to be negative and $a_{2}$ positive.

$$
\log Q_{t}^{S}=a_{0}+a_{1} \log P_{t-1}+a_{2} \log p_{s}+a_{3} \log c_{t}+\log U_{t 2}
$$

Where $Q_{t}^{s}$ is supply of maize, $p_{t-1}$ is the lagged maize price, $p_{s}$ is the soybean price as substitute product for maize and $c_{t}$ is maize production costs. The expected signs of $a_{3}, a_{2}$ are negative and the expected sign of $a_{1}$ is positive.

$$
\log Q_{t}^{d}=a_{0}+a_{1} \log P_{t}+a_{2} \log \text { pop } p_{s}+a_{3} \log B C+a_{4} \log P_{S}+\log U_{t 3}
$$

Where $Q_{t}^{d}$ is demand of maize, $p_{t}$ is maize price, POP is population, BC is demand for meat and $p_{S}$ is the soybean price as substitute product for maize. Therefore, $a_{1}$ is expected to negative and $a_{2}, a_{3}, a_{4}$ all positive.

The final equation in the maize supply/demand system is the maize price equation. The price of maize is determined by supply, import and demand simultaneously, but price also affects the supply and demand of maize. The maize price is modeled as

$$
\log P_{t}=a_{0}+a_{1} \log M I_{t}^{d}+a_{2} \log Q_{t}^{s}+a_{3} \log Q_{t}^{d}+a_{4} \log P_{t-1}+a_{5} \log M I_{t}^{c}+\log U_{t 4}
$$

The sign of $a_{2}$ is expected to be negative and the signs of other parameters to be positive.

After conducting the necessary tests for stationary and diagonal dominance, the maize import, supply, demand and domestic price equations were estimated using three-stage least squares (3SLS). There are several methods for estimating systems of simultaneous equations. The two-stage least squares estimator (2SLS) as one of the most popular ones is efficient and consistent but it ignores information associated with endogenous variables that appear in the system but not in individual equations (Judge et al. 1998). Information concerning the error covariance is also lost (Judge et al. 1998). Another popular method, seemingly unrelated regression (SUR), accounts for the correlation in the error terms across equations but does not consider the endogeneity issues associated with each equation. The three-stage least squares technique is considered as a combination of 2SLS and SUR. It accounts for the contemporaneous correlation in the error terms across equations and the correlation of the right hand side variables with the error term. Furthermore, it is asymptotically more efficient than 2SLS (Judge et al). Because of this, 3SLS is used to estimate the system of simultaneous equations for the maize market identified here. All equations in the system are specified as $\log$-log models (this specification may be called a log-linear model). The parameters of the log-log model can be directly interpreted as elasticities (Gujarati, 1995). The log-log model assumes a constant elasticity over all values of the data set. 


\section{Macrothink}

The effects of scenarios and policies on the maize price can be calculated from the elasticities. With the changes in price, the welfare surplus of Consumer, producer and government and welfare surplus of China and Brazil's maize exports to Iran would change. We estimate social welfare surplus of Iran and exporter welfare surplus for various scenarios (changes in the China and Brazil export price and tariff rates in Iran).

Maize producers are assumed to maximize producers' surplus (PS), consumers maximize consumers' surplus (CS), and government wants to maximize its own surplus (GS) on the maize policy. The government of Iran is assumed to set consumer and farm prices for maize in order to maximize its social welfare surplus. It is consistent with the maximization of the following welfare surplus function

$$
\begin{aligned}
& \text { Maximize } \mathrm{U}=\mathrm{U}(\mathrm{PS}(\mathrm{P}), \mathrm{CS}(\mathrm{P}), \mathrm{GS}(\mathrm{P})) \\
& C S=\int_{0}^{q 0} f(q) \cdot d(q)-q_{0} \cdot p_{0}=\int_{p 0}^{m o} g(p) \cdot d(p) \\
& P S=q_{0} \cdot p_{0}-\int_{0}^{q 0} f(q) \cdot d(q)=\int_{m o}^{Q_{o}} g(p) \cdot d(p) \\
& \mathrm{GS}=(\mathrm{TARIF} * \mathrm{IMPT}) \\
& \mathrm{US}=\left(\mathrm{TARIF}^{*} \mathrm{IMPT}\right)+\mathrm{CS}+\mathrm{PS}
\end{aligned}
$$

Where U represents the social surplus based on producer surplus (PS), consumer surplus (CS), and government surplus (GS), and (US) is the total surplus of society. Each group's welfare depends on the level of policy instruments. Expressions for producer surplus, consumer surplus, and government surplus are derived from the commodity model.

This study analyzes the possible impacts of policy changes in these three countries using a game theoretic approach. The game theory is useful in understanding the nature of market outcomes when such policies matter. The game theoretic approach focuses on the equilibrium for Chinese and Brazilian maize export prices and the Iran tariff rates.

The game theory is concerned with the study of situations involving two or more decision makers such as individuals, organizations, or governments. Decision makers are designated as players. The players often have partly conflicting interests and make individual or collective decisions (Dockner, et. al., 2000). In a game, the fortunes of the players are interdependent: the actions taken by one particular player influence not only his own fortune but also the fortunes of the other players. Such interdependence is well known from many areas of economics and international trade. In this study, there are three players in the game: Iran (IR), Brazil (BR) and China (CH). Let Bk denotes the set of actions available to player $\mathrm{k}$, for $\mathrm{k}=\mathrm{IR}, \mathrm{BR}$, and $\mathrm{CH}$, and let $\mathrm{Bk}$ represents an arbitrary member of this action set. Let (BIR, BBR, BCH) denote a combination of actions, and let Ak denotes player k's payoff function where $\mathrm{Ak}(\mathrm{BIR}, \mathrm{BCH}, \mathrm{BB})$ is player k's payoff resulting from action $\mathrm{BIR}, \mathrm{BCH}$ and $\mathrm{BB}$. A possible outcome of the game can be demonstrated by the following matrix: 
(China and Brazil (player 2) $\quad\left[\boldsymbol{B}_{1} \ldots B_{2} \ldots \ldots \ldots \ldots \ldots . . . B_{n}\right]$

$$
\left(\operatorname { I r a n } \left(\text { player1)) }\left[\begin{array}{l}
A_{1} \\
A_{2} \\
\cdot \\
A_{m}
\end{array}\right]\left[\begin{array}{cccc}
a_{11} & a_{21} & \ldots \ldots & a_{1 n} \\
a_{21} & a_{22} & \ldots \ldots & a_{2 n} \\
\ldots \ldots & \ldots \ldots & \ldots \ldots & \ldots \ldots \\
a_{m 1} & a_{m 2} & \ldots \ldots & a_{m n}
\end{array}\right]\right.\right.
$$

The optimal solution to a game problem may be stated by formulating it as a linear programming problem (Gordon and Ressman, 1978). Bierman et al (1973) formulated a game problem as linear programming. They supposed that the game has two players, countries A and B. Player country A has possible pure strategies A1, A2, .....Am. Player country B has strategies B1, B2, ......Bn, and aij is the payoff to player A when player A is using strategy Ai and player B is using $\mathrm{Bj}$. A mixed strategy for player A consists of a set of probabilities $\mathrm{Xi}$ (for $\mathrm{i}=1$ to $\mathrm{m}$ ), such that $\sum \mathrm{Xi}=1$. Each $\mathrm{Xi}$ represents the probability of using pure strategy Ai. The objective for player $A$ is to maximize an expected value $V$ (the value of the game) as large as possible. The country A can only be sure of the expected value $\mathrm{V}$ if his strategy will guarantee that, regardless of what strategy his opponent adopts; he will obtain an expectation of $\mathrm{V}$ or more. For example, if player B were to adopt B1, then AÕs strategy must be such that

$$
\mathrm{a} 11 \mathrm{X} 1+\mathrm{a} 21 \mathrm{X} 2+\mathrm{a} 31 \mathrm{X} 3+\ldots \ldots \ldots \ldots \ldots \ldots+\mathrm{am} 1 \mathrm{Xm} \geq \mathrm{V}
$$

Similarly if player B uses B2, then to guarantee V, country A must have

$$
\mathrm{a} 12 \mathrm{X} 1+\mathrm{a} 22 \mathrm{X} 2+\mathrm{a} 32 \mathrm{X} 3+\ldots \ldots \ldots \ldots \ldots \ldots+\mathrm{am} 2 \mathrm{Xm} \geq \mathrm{V}
$$

A similar condition holds for any strategy which player B may play. Hence the linear programming problem for country A is

$$
\text { Maximize V }
$$

Subject to

$$
\begin{aligned}
& \mathrm{a} 11 \mathrm{X} 1+\mathrm{a} 21 \mathrm{X} 2+\ldots \ldots \ldots+\mathrm{am} 1 \mathrm{Xm}-\mathrm{V} \geq 0 \\
& \mathrm{a} 12 \mathrm{X} 1+\mathrm{a} 22 \mathrm{X} 2+\ldots \ldots \ldots+\mathrm{am} 2 \mathrm{Xm}-\mathrm{V} \geq 0
\end{aligned}
$$

$\mathrm{a} 1 \mathrm{n} \mathrm{X} 1+\mathrm{a} 2 \mathrm{n} \mathrm{X} 2+\ldots \ldots \ldots+\mathrm{amn} \mathrm{Xm}-\mathrm{V} \geq 0$

$\mathrm{X} 1+\mathrm{X} 2+\ldots \ldots \ldots+\mathrm{Xm}=1$

all $\mathrm{Xi} \geq 0$

The last equation guarantees that the probabilities add up to one. The solution to this problem gives the equilibrium mixed strategy $(\mathrm{X} 1, \mathrm{X} 2, \ldots \mathrm{Xm})$ for player $\mathrm{A}$ and the value of the game 
$\mathrm{V}$. The dual of the linear programming problem for player $\mathrm{A}$ is the primal problem from player B's point of view. Let $(\mathrm{B} 1, \mathrm{~B} 2, \ldots . . \mathrm{Bn})$ be the mixed strategy probabilities for player B. The solution gives the optimum strategy for B $(\mathrm{B} 1, \mathrm{~B} 2, \ldots . . \mathrm{Bn})$ and the value of the game. Thus, using this method, the optimal tariff rate for Iran and the optimal maize export prices for Brazil and China are computed.

\section{Analysis of Results}

As seen in Table 3.1, all independent variables in the equations have strong statistical significance and expected signs. All equations exhibit high R2 values Over 90 percent of the variation in supply, demand, import and price are explained by the models.

All of the independent variables are statistically significant at the 5\% significance level in the import case from China and Brazil. As the difference between the Chinese and Brazilian maize price and domestic retail price widens, the willingness of producers to export maize trends to increase and the ratio of export prices to domestic prices of Chinese and Brazilian maize becomes negative as -0.36 and -0.42 , respectively. This indicates when the ratio of export prices to domestic prices increase by $1 \%$, the demand for maize from China and Brazil decreases by approximately 0.36 and 0.42 , respectively. The estimated import function from these two countries shows that the impact of domestic production on import demand in Iran is the greatest in terms of the magnitude of coefficients; it can be concluded that the domestic production is viable variable on imported demand in Iran. If we are a major importer, an increase in the tariff rate causes exporters decrease their prices, implying tariff has a positive impact on our economy. As Iran is a insignificant country in maize export, so an increase in the tariff rate may cause an increase in domestic price of maize. Hence, we can conclude that tariff has an important role in the maize market of Iran.

The lagged price elasticity for domestic supply is inelastic (0.89), revealing that farmers response to price is inelastic. Maize consumption is negatively related to its own price and the demand price elasticity is 0.72 , which indicate maize is essentially good for consumers in Iran. The elasticity of per capita GDP as income is also computed to be 0.375 , implying that maize is a normal good in terms of income in Iran.

The impacts of imports from China and Brazil on domestic maize price in Iran are the greatest in terms of the magnitude of coefficients. Demand has the second greatest impact, and domestic supply follows. The results from the price equation suggest that import demand from China and Brazil is more important in explaining maize price than other used variables.

Tariff on imports is considered one of the most supportive important tools that can positively or negatively act on domestic production. Tariffs should be effective so that support the production of agricultural products, but unfortunately in the agricultural sector this balance has not happened in recent years. On the other hand, as Iran intends to join the WTO agreement and help consumers and Iran is optimistic about joining the World Trade Organization (WTO) by 2017 if political influence is not an issue, it can't increase tariff rates but it should be decreased. Of course It should be noted that Iran joining to WTO has a different welfare effects on society, which can be discussed in detail in another study, on the 
other hands it can be a good idea for another study. Tariffs should be set in a way to support producers and consumers and provide necessary conditions for Iran to join the WTO agreement. Tariff rates for maize import is now considered about $4 \%$ and the possible reduction range of tariff rate would be from $0 \%$ to $10 \%$ annually. This reduction rang is taken into account for the scenario analysis. In 2009, retail price of maize in Iran was 2492 Rials and the export price of China and Brazil were 2091 and 2217 Rials, respectively. This means that the ratio of export prices to domestic price was estimated to be 0.89 and 0.84 for China and Brazil, respectively. The range of 0.56-1.38 is considered for the scenario analysis for both countries to obtain the Nash equilibrium

Table (3.1). Empirical results of import from China and Brazil, domestic supply, demand and price functions

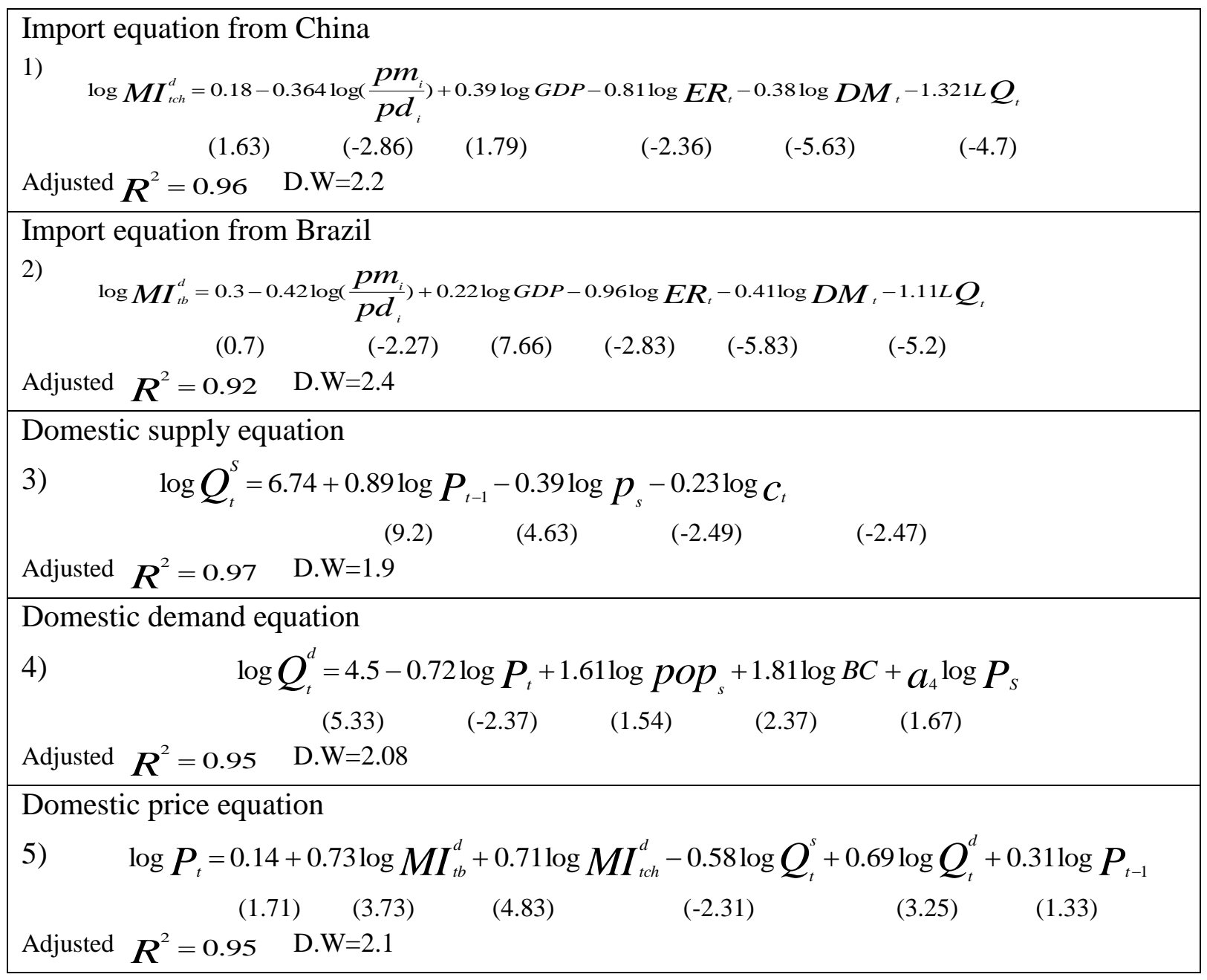

The simulation results associated with the policy scenarios are summarized in Tables 3.2 and 3.3. These are the payoffs for the two countries under Nash equilibrium.

The left hand column in the table 2.3 indicates the changes in Iranian tariff rates from the base level in 2009. The top of tables indicates the changes in China and Brazil export price on domestic price of Iran. The numbers under each export price and tariff scenario denote the 
welfare in three countries in million Rials $(\$ 1=10,000$ Rials approximately).

The Nash equilibrium solution is shown in bold letters in Tables3.2. As seen in Tables 3.2 and 3.3, China and Brazil obtained 0.93 and 0.98 in the Nash equilibrium solution, with the payoff of 263 and 559 milliard Rials, respectively. As seen, Iran tries to keep its tariff rate as high as possible to restrict imports and support domestic producers. Therefore, given the Nash equilibrium obtained, Iran has to choose the $8 \%$ tariff rate to maximize its payoff. Under this scenario, the payoff is equal to 7138 milliard Rials for Brazil and China, respectively. If government chooses a higher or lower tariff rate than $8 \%$, it has inverse effects and neither support farmers and consumers, nor improve social welfare. The first numbers in a solution cell represent Chinese payoffs, and second numbers represent Iranian payoff

Table (3.2). The payoff game theory for Brazil and Iran (million Rials)

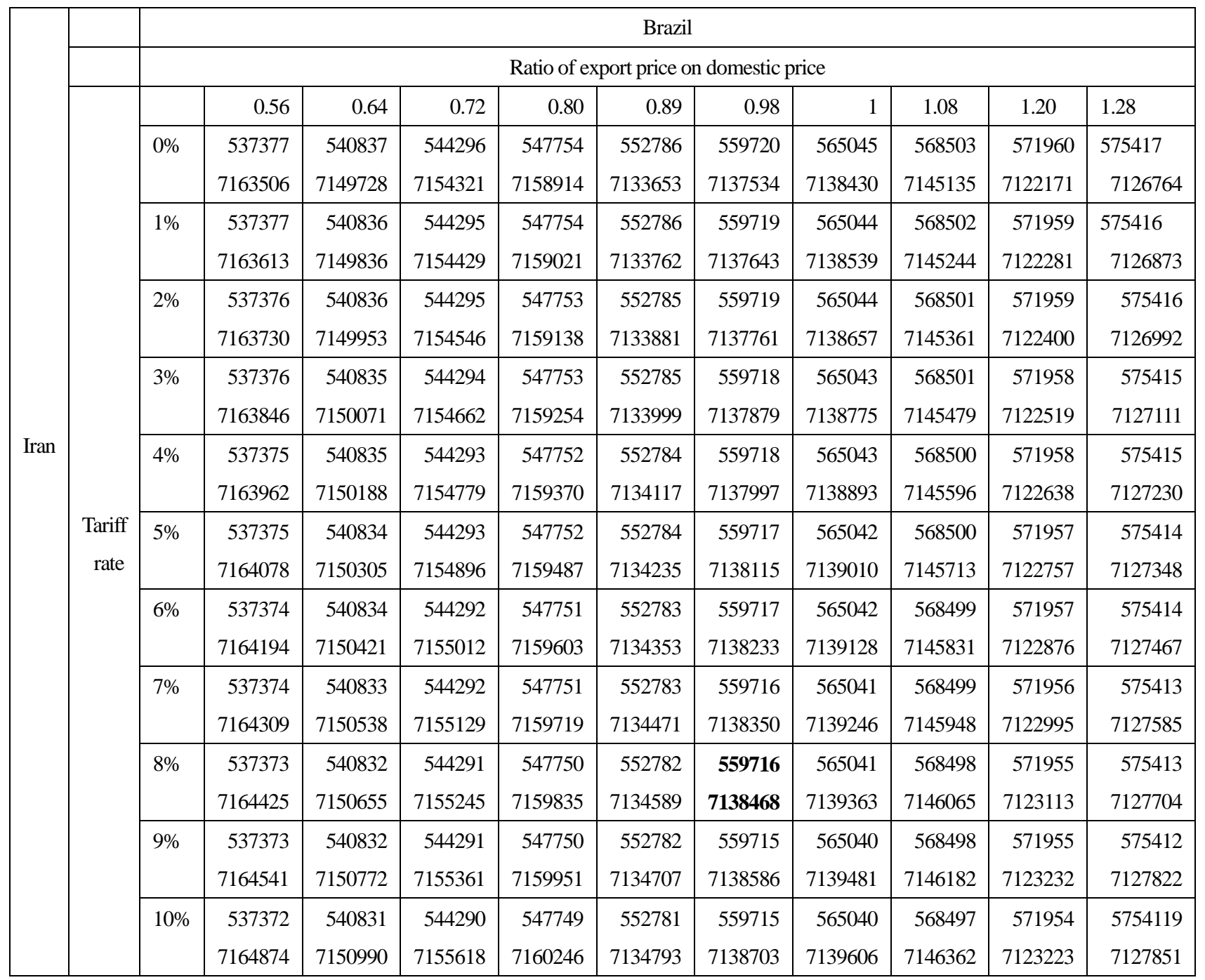




\section{$\triangle$ Macrothink}

Journal of Agricultural Studies

ISSN 2166-0379

2013, Vol. 1, No. 2

Table (3.3). The payoff game theory for China and Iran (million Rials)

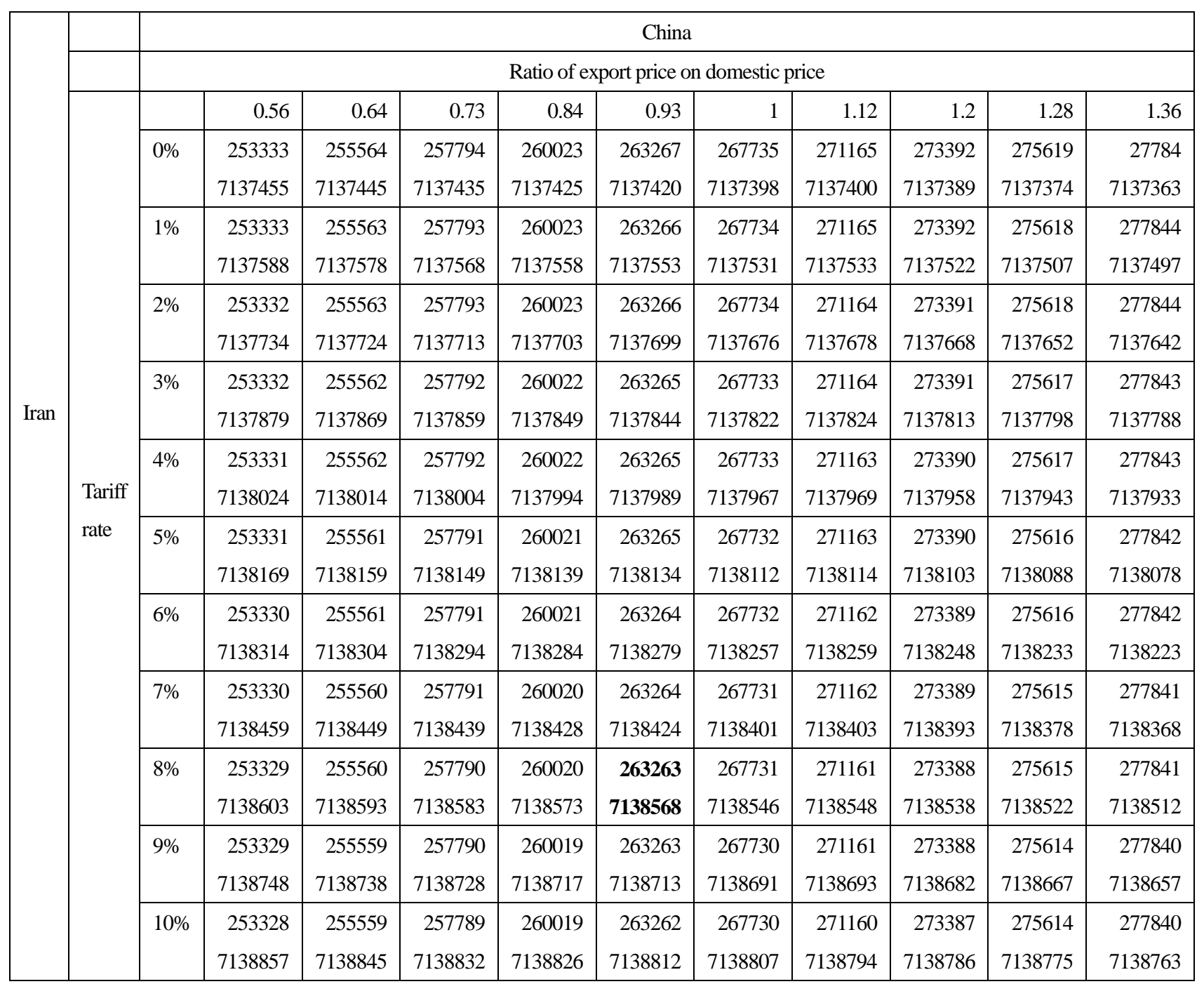

\section{Conclusion}

In this study, the interaction between Iran's maize imports and China's and Brazil's maize exports are analyzed using a game theoretic approach. The maize market in Iran is analyzed using empirical supply, demand, retail price and demand imports, and elasticity estimates. A social welfare approach is applied to measure the payoff matrix for these countries under the variation of import tariff in Iran and export prices in China and Brazil. The welfare level of maize producers and consumers changes as a result of changes in the price of maize created by these variables.

In recent years, the Iranian government has attempted to impose lower tariff rates on maize (the maize tariff was 4 percent in 2009). While with this tariff rate domestic maize producers can be harmed if the import price is less than the domestic producer price, our results suggests that a higher tariff rate, e.g. approximately $8 \%$, will maximize social welfare under 0.93 and 0.98 ratio of export price to domestic price for China and Brazil respectively. These rates are much more than the actual tariff rate and export prices imposed by the three countries. 


\section{Acknowledgment}

The authors would like to acknowledge the financial support of University of Tehran for this research under grant number (96610047-6-3).

\section{References}

Burhan, O., \& Handan, A. V. (2001). Game theory and its application to field crops in Antalya province. Department of agricultural economics, Antalya, NCCC-134.

Bakhshoode, M. (2012). Application of game theory to measure social welfare policy of Iran's rice imported tariffs and The export tax of Thailand. Agricultural Economics, 34, 17-23.

Carter, C., \& Schmitz, A. (1979). Import tariffs and price Formation in the World Wheat Market. American Journal of Agricultural Economics, 61. http://dx.doi.org/10.2307/1239439

Daniel, O. (2010). World maize market supply-demand trends. American journal agricultural economics, 61, 176-284.

Gujarati. (1995). Basic Econometrics. (3rd ed.). McGraw-Hill, Inc.

Hwanil, P., \& Randall, F. (2007). The effect of ethanol production on the u.s. national maize price. Proceedings of the Conference on Applied Commodity Price Analysis, Forecasting, and Market Risk. NCCC-134.

Judge, H. G., \& Lee. (1988). Introduction to the Theory and Practice of Econometrics. In John Wiley \& Sons, Inc. (2rd ed.).

Larr, S., A., \& Mccall, F. (1983). Dynamic games and international trade: an application to the world maize market. American Journal of Agricultural Economics.

Lee, D., S., \& Kennedy, P. L. (2002). A Game theoretic analyzes of U.S rice export POLICY: the case of Japan and Korea. presented at the annual meeting of the American Agricultural Economics Association, Long Beach, California, July 28-31.

Najafi, B. (1999). Evaluating Government policies in Agriculture sector. The Iranian ministry of Agriculture (in Persian).

Nicita, A. (2009). The price effect of tariff liberalization :measuring the impact on household $\begin{array}{lllr}\text { welfare. Journal of development } & \text { Economics, } & \text { 89, }\end{array}$ http://dx.doi.org/10.1016/j.jdeveco.2008.06.009

Paul., C, W., \& Linwood, A. (1999). Price Determination for Maize and Wheat: The Role of Market Factors Government Programs. Market and Trade Economics Division, Economic Research Service, U.S Department of Agriculture. Technical Bulletin No. 1878.

Salvador, R., J. (1997). Maize in the Encyclopedia of Culture and Society of Mexico. Fitzroy Dearborn Publishers

Salami, H., \& Bakhshode, M. (2011). Welfare analysis of government intervention in wheat 


\section{Macrothink}

Journal of Agricultural Studies

ISSN 2166-0379 2013, Vol. 1, No. 2

markets and its effects on barley market whit game theory. Journal of Agricultural Economics and Development, 26(2), 106-116.

Sidney, M. (1962). A game theory model for agricultural crop selection Econometric, The International Trade Journal, 2, 221-223.

Sloof, R. (1998). Game theoretic models of the political influence of interest groups Boston: Kluwer academic publisher.

Yazdani, S., \& Shahbazi, H. (2008). Corn Import Demand Model in Iran; Political Factors Application. American-Eurasian J. Agric. \& Environ. Sci., 4(5), 633-639.

\section{Copyright Disclaimer}

Copyright reserved by the author(s).

This article is an open-access article distributed under the terms and conditions of the CreativeCommons Attribution license (http://creativecommons.org/licenses/by/3.0/). 